\title{
The Image of Chemistry Presented by the Science Museum, London in the Twentieth Century: An International Perspective
}

\author{
Peter Morris
}

\begin{abstract}
How has chemistry been presented at the Science Museum, London, during the $20^{\text {th }}$ century? After an overview of the history of the Science Museum and its chemistry galleries, four galleries are considered in depth (1906, 1926, 1977, and 1999). The importance of the curators' external constituency of chemists and chemical educators is emphasized. The image of chemistry at the Science Museum has concentrated on the general utility of chemistry and chemistry as a skilful craft. The presentation has been low-key rather than boosterist. A comparison is made with the chemistry galleries at the Deutsches Museum. Chemistry in the Deutsches Museum has put more emphasis on hands-on exhibits and the chemical industry. Science and technology museums have promoted chemistry in a quiet but successful way for many years, but their influence may have waned along with chemistry kits.
\end{abstract}

Keywords: presentation of chemistry in museums, chemistry collections, chemistry galleries, Science Museum, Deutsches Museum.

\section{Introduction}

Before we examine the image of chemistry that has been presented by the Science Museum during the 20th century, it is worth asking if science and technology museums have any influence on the public's perception of chemistry. While the impact of museums is inevitably less than, say, the mass media, they do attract large audiences: the Science Museum had 1.2 million visitors in the 1930s, a peak of 4.2 million visitors in 1980 and 2.6 million visitors in 2004. It is also clear that such museums have a strong and lasting emotional effect on some visitors. The impact of museums is also important insofar as they appeal to young people whose image of chemistry may not be completely formed. If we accept that the way museums portray chemistry can have an impact on its public image, has the presentation of chemistry in museums 
changed over the years and in what way has their portrayal of chemistry changed? How do museums develop their chemistry displays? Are they created purely by the curators, by an external group of leading chemists and chemical educationalists, or are they shaped by the visitors themselves?

As a curator in a leading science museum who has both looked after and developed chemistry galleries, I am able to show how chemistry is displayed in museum from the curatorial point of view. On one hand this means that I am able to see influences and connections which might be missed by an external observer. I also have access to printed materials and documents that an external author might not be aware of. I have been able to discuss developments in the Science Museum with colleagues whose experience goes back to the 1970s. On the other hand, my analysis will be limited by being a curator, my view although deeper will inevitably be narrower than that of an acute external observer. However, I believe this exercise is worthwhile. This is a good time to take stock as museums have changing radically over the last few years and will continue to change. We are not likely to see entire galleries devoted to academic chemistry in the future. My main aim is to present an insider's view of gallery development and to show the importance of external influences. I do not seek to place these developments within the latest historiography, nor am I able within the limits of this paper to place these galleries within their broader museological and educational contexts. Nonetheless, I hope this paper will provide the material for future research on these aspects of the topic.

The term 'chemical gallery' can mean many things and can cover many different areas of chemistry, broadly defined. For example, chemistry galleries often cover the chemical industry and its products including plastics and metals. It might be argued that any study of the development of chemistry galleries should cover these outlying fields. In practice, however, I have found that the image presented by the chemical industry displays of chemistry galleries is very different from that by academic chemistry exhibits. Therefore, the image of industrial chemistry will be the subject of a subsequent paper.

\section{History of Chemistry at the Science Museum}

The Science Museum has its origins in the South Kensington Museum which was founded in 1857 following the great popularity of the Great Exhibition of 1851 which garnered a considerable financial surplus (Hobhouse 2002). The mission of the South Kensington Museum was the promotion of art and science, art in this context being what we would now call crafts and design, and it came under the control of the Department of Science and Art (Follett 
1978). The relatively few chemistry exhibits were in the wall cases of the Education Museum, which was part of the South Kensington Museum. The science and engineering collections were expanded after the Royal Commission on Scientific Instruction and the Advancement of Science ('Devonshire') Commission reported on the South Kensington collections in its fourth report of 1874. As a consequence, the Royal Commission for the Exhibition of 1851 offered to build a science museum if the government provided the site, but this offer was not taken up. For their part, the Lords of Committee of the [Privy] Council on Education, led by Viscount Sandon, set up a committee chaired by the Lord Chancellor (Baron Cairns) to organize a temporary international exhibition of scientific instruments (Special Loan Catalogue 1876). This Special Loan Exhibition held in 1876 was supported inter alia, by Frederick Abel, Edward Frankland, Jean Baptiste Dumas, and Wilhelm Hofmann. It was displayed in the Western Galleries of the Royal Horticultural Society's exhibition halls, which had originally been erected for the International Exhibition of 1862. The Special Loan Exhibition was an important watershed in the development of the Science Museum as many of the objects on loan for this exhibition were left at the museum, although only a few in the case of chemistry, including demonstration apparatus developed by Hofmann.

After the control of the Patent Museum moved from the Commissioners of Patents to the Department of Science and Art in 1883, that museum was amalgamated with the Science Museum. This collection had hitherto been completely distinct in institutional terms, but displayed alongside the South Kensington Museum in the so-called 'Brompton boilers' (from the appearance of the buildings and their location on the Brompton Road). The non-art collections of the South Kensington Museum had been known as the Science Collections, presumably to reflect the dichotomy in the title of the Department of Science and Art, and following the amalgamation with the Patent Museum, the Department changed the name of the collections to the Science Museum. As Sir Phillip Cunliffe-Owen was still in post as Director of the South Kensington Museum, a separate director for the Science Museum was not appointed until he retired in 1893. The first director was Major-General Edward R. Festing FRS, who had joined the South Kensington Museum in 1864, and had explored the potential of infrared spectroscopy as an analytical tool with Sir William Abney in the 1880s.

The Science Museum's collections were transferred in 1888 from the South Kensington Museum to the Western and Southern Galleries occupied up to that date by the Royal Horticultural Society. Science was in the Western Galleries, which were to the west of the current Imperial College Library building. They were smaller in area than the Southern Galleries and away from the main entrance on Exhibition Road. The Western Galleries did not 
attract many visitors, only 86,216 in 1908 compared with 384,889 for the technological collections in the Southern Galleries (Board of Education 1909). In fact the name 'Science Museum' has always been a complete misnomer. Technology not science has always been the dominant aspect of the Science Museum and until the directorship of the chemist and historian of chemistry Frank Sherwood Taylor in the early 1950s, chemistry was a relatively minor part of the Science Museum's displays. The modest chemistry galleries were on the first (top) floor of the Western Galleries at the north end just to the south of Prince Consort Road, near the present-day Blackett Laboratory of Imperial College.

The South Kensington Museum was renamed the Victoria and Albert Museum in 1899, when Queen Victoria laid the foundation stone of the new building for the art collections. By what seems to have been a bureaucratic oversight, the Science Museum was considered a division of the Victoria and Albert Museum. In 1909, the famous chemist and politician Sir Henry Enfield Roscoe led a delegation of scientists and engineers to the new Board of Education to demand that greater attention be given to the development and accommodation of the Science Museum's collections. The Science Museum was at long last separated from the Victoria and Albert Museum in the same year, when the latter's building was formally opened by King Edward VII. A Departmental Committee was set up in March 1910 to advise on the future direction of the Science Museum and to recommend what new buildings were required. It was chaired by Sir Hugh Bell, a director of the steel firm Dorman Long and a former Mayor of Middlesbrough. He was the son of the leading ironmaster Sir Isaac Lowthian Bell and the father of the explorer and orientalist Gertrude Bell. In a landmark report in 1911, the Bell Committee laid out the future of the museum, proposing the construction of three wings (or blocks) in turn, beginning with the East Block on Exhibition Road. Construction began in 1913, but World War I intervened and the half-finished building was taken over by the Civil Service for war use. The East Block was finally opened by King George V in 1928, but the Central Block was not finished until 1961. The West Block (now called the Wellcome Wing) only saw the light of day in 2000, almost nine decades since the publication of the Bell Report which had envisaged the completion of the central block in 1923 and the West Block as and when required a few years later!

The period between 1916 and 1925 was a dismal period for chemistry in the Science Museum largely because of World War I. The museum was closed to the general public in March 1916 and the chemistry gallery was occupied by clerks from the War Office between 1917 and 1921. The space vacated by the War Office was then taken over by the new Imperial War Museum Library just over a year later (Board of Education 1924a/b). There was still some chemistry (and industrial chemistry) on display, but space was very 
limited. Matters improved when the East Block was fitted out in 1925 and 1926. Chemistry and industrial chemistry, which had been brought together in 1912, were on the third floor of the new East Block, and the new gallery was opened to the public in April 1926 (Board of Education 1926). This gallery - Gallery 66 in the museum's internal numbering scheme - is now a mixture of offices and simulators. In this period, the chemistry collections were curated by Alexander Barclay, an Imperial College (Royal College of Science) educated chemist who had joined the museum in 1921 when he was taken on to help with the preparations for the new gallery and who became an Assistant Keeper in 1930. Eight years later, he became the Keeper of Department IV (chemistry, photography, optics, astronomy, and mathematics, which became chemistry and photography in 1949 [Who Was Who 1991]). The museum was closed to the public between September 1939 and February 1946, except for a brief period in the spring (February-June) 1940.

Chemistry increased in importance following the appointment of Frank Sherwood Taylor as director in 1950. Taylor died in office after serving for only six years. He was in conflict with his Keepers who opposed his publications on science and religion, but he promoted the career of Frank Greenaway, an Oxford-trained chemist who had joined the museum as an Assistant Keeper in 1949. Greenaway, as the first chemistry curator to be an active historian of chemistry, was to have a decisive influence on the presentation and development of chemistry at the Science Museum in the 1960s and 1970s. The Chemistry and Industrial Collections had mostly been moved into store during World War II. The task of putting the collections back on display occupied the Chemistry Department for ten years. Chemistry returned to Gallery 66 on the third floor in 1952. The redisplay of Industrial Chemistry in Gallery 46 on the second floor took place very slowly with considerable input and some financial support from industry. The Industrial Chemistry gallery was still only partly completed in 1957 (Science Museum Guides 1952, 1953, 1957). Barclay was succeeded as Keeper of Chemistry and Photography in 1959 by Stanley Janson, a Cambridge-trained chemist who worked on the industrial chemistry collections and especially glass technology (Science $\mathrm{Mu}-$ seum 1970).

After building the new chemistry and industrial chemistry galleries on the second floor of the East Block in 1963-4, Greenaway became Keeper of Chemistry in 1967 while Janson, who retired two years later, became Keeper of Astronomy and Geophysics. Greenaway built up a team of young enthusiastic and knowledgeable curators - including Robert Anderson, Derek Robinson, and Ann Newmark - who were responsible for the revamping of the chemistry and industrial chemistry galleries in 1977. Greenaway was succeeded in 1980 by Robert Anderson, who left the museum in 1984 to become Director of the Royal Scottish Museum (subsequently the National Museums 
of Scotland). The chemistry department was then amalgamated with the physics department and the new Keeper was the former Keeper of Physics, David Thomas (who had been an Assistant Keeper of Chemistry between 1961 and 1973). During this period Robert Bud curated a new chemical industry gallery sponsored by ICI in 1986. On Thomas's retirement in 1987 he was succeeded by Derek Robinson who had become Keeper of Museum Services in 1978. He was given the new title of Head of Physical Sciences when the keeperships were abolished soon afterwards. Robinson took personal charge of Industrial Chemistry and Ann Newmark was Senior Curator of Experimental Chemistry. When Newmark became Head of Documentation in 1991, she was succeeded by Peter Morris who also took over Industrial Chemistry on the retirement of Derek Robinson in 1999 (by then Head of Physical Sciences \& Engineering). The chemistry galleries on the second floor were cleared in the same year and replaced by a much smaller gallery entitled 'The Chemistry of Everyday Life'. The industrial chemistry gallery was cleared a few years later in 2004.

\section{Gallery Development at the Science Museum}

From my own experience as a curator and drawing on the experiences of my colleagues and former colleagues at the Science Museum, I believe that it is possible to show how the development of a new gallery is shaped by external factors; for a very different view of gallery development by an external observer, see Macdonald 2002. Up to now, all the chemistry galleries at the Science Museum have been put together, if not explicitly designed, by curators. In order to understand the development of these galleries we need to understand the environment in which these curators operate. We have to begin with the curators themselves. Nearly all the curators who have had a major influence on the chemistry galleries have been chemists, at least four of them were even Fellows of the Royal Society of Chemistry or its predecessor, the Royal Institute of Chemistry. To a lesser or greater extent they have also been interested in the history of chemistry and in more recent times, they have been professionally trained historians of chemistry. In passing it should also be noted that they have also been predominantly white and male, and have gone to leading English universities, especially Oxford and Manchester.

As employees of the Science Museum, the work of curators is overseen by the Director, once a hands-on manager of new galleries, but now somebody who has to concentrate on the strategic management of three museums, and by an advisory council (the Board of Trustees since 1983) made up of leading scientists, engineers, and other members of the establishment. Also the gov- 
ernment has had some influence, initially through the Department of Education and Science (and its predecessors) and more recently via the Department of Culture, Media, and Sport. The government's influence on gallery development deserves closer examination, but it would be fair to say that it was until recently - minimal as far as specific galleries were concerned. As long as the galleries promoted science education in a broad sense and did not generate politically embarrassing controversy, the Department was happy to leave the content of the museum's displays to the Director and his staff. Nonetheless, since the 1960s the government has increasingly pushed museums to seek external funding for new galleries and, since the late 1980s, to cater for increasingly diverse audiences.

As civil servants until 1983, and as government employees even now, curators operated within a specific institutional ethos. Their personal political and religious views were not supposed to impinge on the content of displays, and I have not found any case where this has in fact occurred. The civil service ethos has also ensured that curators have worked with external bodies and companies in an even-handed manner, not favoring one firm's products over a rival's, or one institution's research over another. There are some exceptions to this general rule of neutrality. There has been a tendency to highlight the work done by other government bodies, such as the Laboratory of the Government Chemist. The museum has also been supportive of the aims of professional societies and official industry-wide organizations - such as the Royal Society of Chemistry and the Association of British Chemical Manufacturers - and it has worked closely with these organizations over the years. Finally for geographical and personal reasons, the chemistry curators at the museum have tended to work closely with leading London colleges (Imperial, UCL, and King's) and to a lesser extent with Oxford and Cambridge. For the same reasons, they also frequented the showrooms of the leading Londonbased scientific instrument suppliers and manufacturers, which were a leading force in the industry up to the 1960s. Although there is no evidence that the curators favored one firm's products over another, some companies were better than others at donating objects, as I know well from personal experience. Up to the mid-1960s, firms often lent objects on the assumption they could be 'silently' replaced by more up-to-date models over the years, although in practice the museum often retained the initial object. It has to be emphasized however, that 'branded' instruments always formed a minority of the museum's chemistry collections, at least until recently.

In theory a new gallery could have a client, an external person or body, who has funded or at least has provided moral support for its construction. Certainly this would almost invariably be the case nowadays, but most of the galleries considered here were developed without external funding and the only client-funder was the government. But when there has been an external 
sponsor, we have taken the client's aspirations for the gallery into account, but have also taken great care not to give a client any undue influence on a gallery's content. At the same time, industrial and institutional sponsors (notably ICI and the Royal Institute/Society of Chemistry) have shaped the content of galleries over the years by offering advice, making donations of objects, making exhibits (for instance, the model of an ammonia plant in the 1977 Industrial Chemistry Gallery) and by generally stimulating the development of the content. For example, the Royal Society of Chemistry set up working parties to produce interactives for the 1999 Chemistry Gallery.

There is, however, one key aspect of the development of galleries which has not been widely understood and that is the importance of the curators' 'constituency'. Curators have historically had a dual role similar to that of Members of Parliament. On one hand they represent the museum to their external constituency and on the other they are the representatives of that constituency within the museum. The chemistry galleries have largely been a product of this curatorial interaction with their constituency. But what is a 'constituency' in this context? It can be defined as a group of educated people that a curator enjoys strong links with and wishes to gratify and impress. Although it is often said that curators create galleries for other curators, this has never been the case for the chemistry galleries, partly for the lack of any similar curators to impress. The chemistry curator's constituency is first and foremost other chemists, including biochemists and industrial chemists, particularly leading chemists and chemical educators. Chemical societies and industrial chemical organizations also play an important role, but less than might be imagined. Their influence has greatly varied from gallery to gallery and thus over time. Historians of chemistry and other historians of science have become increasingly important members of the constituency, especially since the formation of the Society for the History of Alchemy and Chemistry in 1937, but their influence has never been as great as that of the chemists. This constituency can easily be distinguished from the Advisory Council as the board always included only a small number of chemists. There were no chemists on the Advisory Council in the 1920s, and Trevor Williams, the historian of chemistry and editor of Endeavour, was one of the few chemists in the 1970s. Professor Arthur Smithells, who advised the museum on the chemistry display in the early 1920s, was never on the Advisory Council; and Professor Edward T. Hall, a key advisor to the curators during the 1977 redisplay of the chemistry galleries, only joined the Advisory Council two years later in 1979. While this lack of chemists on the council gives this constituency a heightened importance, I would argue it would always have been more important as it was a larger group and furthermore a group close to the curators' own intellectual and social milieu, for instance, through meetings of the Chemical Society at Burlington House, Annual Chemical Congresses, and 
social events at the Royal Institution. It has to be emphasized that this constituency has never been the target audience for the gallery, the actual audience for the gallery, or even an influential group of visitors. Paradoxically many members of this group rarely visited the museum. They influenced the gallery at the planning stage not as commentators on an existing gallery. Their direct experience of the museum would have taken place when they were schoolchildren or students. In more recent times, they would have only seen the chemistry galleries on special occasions, such as gallery openings, or when taking their children or grandchildren to the museum.

Despite the current emphasis on meeting the needs of a 'target audience', the putative audience for the chemistry galleries did not play a major role in shaping the content or design of these galleries until the last chemistry gallery in 1999. The collections were taken as a given and the displays were constructed to house them. To be sure, the curators have always had an idea of the kind of people they were addressing, but in the absence of detailed knowledge of the needs or interests of general visitors, how did the curators gauge the needs of their audiences? Senior members of staff were encouraged to mingle with visitors on the galleries and ask them for their impression of the displays. To some extent they must have also been influenced by the views of their family and friends. Successive Directors, especially Sir Henry Lyons, ensured that any new displays met the needs of the ordinary visitor as laid down by the Bell Report. Here too, nonetheless, the constituency played an important role. If the displays met with the approval of the constituency it was assumed to be suitable for the public at large, not least because many of its members were educators or public lecturers.

\section{The Image of Chemistry Presented by Science Mu- seum Galleries}

As we are looking specifically at the image of chemistry, I have deliberately chosen not to examine industrial chemistry, plastics, and metallurgy, all of which have been displayed with chemistry over the years, although these subject areas have had their own galleries in more recent times. However, precisely because they were displayed alongside chemistry and developed by the same curators, excluding these related subjects will not make any significant difference to my analysis with the marked exception of the 1986 chemical industry gallery, which introduced a striking and original 'mythopoetic' approach into the Science Museum. I have built up a picture of the different galleries by examining the printed catalogues and photographs. The archival records are sparse, but there are valuable comments in the annual reports for 
the earlier galleries and for the more recent ones I have been able to obtain recollections from the relevant curators. I would argue that the objects displayed on the galleries are central to understanding the image of chemistry the curators sought to communicate to visitors and their constituency. This is fortunate, for it is relatively easy to find out what objects were specifically acquired for a new gallery and which ones were considered to be of particular significance by the curators. The new objects illustrate changes in chemical practice but also in the curators' changing aims for the gallery. Of course, the objects are only part of the story, and the medium - the display - is a vital part of the image production. Although there are fewer photographs than one would like, especially for the earliest galleries, it is possible from these photographs to make an intelligent analysis of the display techniques which were used.

\subsection{The Western Galleries, 1890-1916}

The chemistry galleries in the Western Galleries existed from 1890 to 1916. They were lofty and generously illuminated by natural light, in many respects similar to the Smithsonian's Arts and Industries building which opened in 1881. The cases were traditional mahogany cases with elegant piano-style legs. They were fairly tall and judging by the photograph of the Time Gallery from this period tended to dwarf the smaller objects in them. In the late $19^{\text {th }}$ century the museum was very much under the thumb of the Department of Science and Art (Board of Education from 1900) of which it was a part. The emphasis was on current scientific practice and on education of young people, almost entirely men, embarking on a technical or scientific career. Part of the purpose of the museum was to show teachers, including college lecturers, the latest scientific apparatus and achievements. The constituency was a combination of scientific civil servants (e.g. William Abney, Frederick Abel), leading chemists (e.g. Henry E. Roscoe), the staff at Imperial College (who could borrow the apparatus), educationalists, and the scientific instrument trade which was very active in London until the 1960s.

The chemistry collections were very small in the early 1880s and they did not benefit from the amalgamation with the Patent Museum, so that there was a need to acquire a large number of objects. Most of these new acquisitions were new scientific apparatus lent or (more rarely) donated by scientific instrument makers and suppliers (Catalogue 1906). Various set-ups for gas analysis were particularly well represented, perhaps reflecting the importance of the gas industry and the steel industry in the late Victorian period. There were a few historical pieces but they were greatly outnumbered by chemical specimens. The emphasis was on copies or replicas rather than the 'original'. There was a copy of Cailletet's oxygen liquefaction apparatus, a replica of Moissan's apparatus for the isolation fluorine, and a Bunsen thermostat (for 
keeping gas samples at a constant temperature) purchased from the firm established by Bunsen's technician Peter Desaga. The tenor of the display was thus a mixture of the trade show or international exhibition and the 'chemical museum' which was often found in larger chemistry departments (such as in Manchester, Leeds, Columbia in New York, and Berlin) which consisted almost entirely of chemical samples. By 1906, the key objects on display also included the collection of the elements bequeathed by Prince Louis Lucien Bonaparte in 1891, the diffusion apparatus used by Thomas Graham, a balance constructed by John Fidler around 1800, the Tintometer developed by Joseph Lovibond, and a model of a school laboratory in Leiden which had been on display at the Special Loan Exhibition. The method of display was what would now be called 'visible storage': cases filled with a large number of objects and packed close together in rows. The captions appear to have been often long descriptions of the objects and the techniques they represent. There does not appear to have been any attempt at an overarching narrative or a unifying theme. It is difficult to tell how the gallery was organized in the absence of a gallery plan, but the 1906 catalogue hints at an arrangement by use ("general use", "demonstrations", "special researches", and "technical gasanalyses") rather than by sub-discipline.

In the Western Galleries, chemistry was presented as a comparatively new science which was developing rapidly; there was nothing connected with alchemy and no attempt to give chemistry a distant past. There was an emphasis on the use of intricate apparatus and the use of different methods of achieving the same aim, such as, for instance, fat extraction. The display of samples showed that chemistry was capable of making many different products. The overall effect is one of skill and complexity, neither showing the negative side of chemistry nor aggressively promoting the positive aspects. This display was for the visitor who knew or was learning chemistry and it showed him what the curators perceived as being relevant. The ordinary visitor would have been captivated by the sumptuousness of the brass and fine woods, the elegance of Hofmann's demonstration apparatus, the quirkiness of the Bunsen thermostat, and the mysteriousness of elements. But this would be an almost accidental by-product of the development of the gallery. I say 'almost' because the curators must have been aware of the public's interest in what they could appreciate but not really understand. While they would have accepted this interest, it was not the curators' aim to reach out the general public, but to engage with chemists and their students.

\subsection{Chemistry in the East Block, 1925}

The Bell Report of 1911 introduced a new line of interpretation which put a greater emphasis on history and the development of science and technology. It called for the "preservation of appliances which hold honoured place in the 
progress of science" (Follett 1978, p. 21). While the specialist, the technical visitor and the student were still important audiences, the Bell Report and the new Director of the Science Museum from 1920, Henry Lyons, put the ordinary visitor first (Follett 1978, p. 98). There was not enough time to develop this new approach in the Western Galleries before World War I, even if the curators had been keen on it and I suspect they were not. By the time the East Block became available in 1925, there was new blood in the form of Alexander Barclay and the changes in approach were evident in the new chemistry gallery on the third floor. While the approach and the target audience may have changed, the constituency remained much the same as it had been in the 1880s, namely leading chemists and chemical educators together with the scientific instrument trade. For instance, the proposed display scheme was checked by Professor Arthur Smithells (Z Archive, 1924).

The new gallery had a specific aim "to give a general idea of the chief branches of chemistry" (Board of Education 1931) and "the development of chemistry from earliest times" (Science Museum Guide 1937). But it was not typological in the manner of Pitt-Rivers: there was no attempt to show the 'evolution' of chemistry. With a new emphasis on history, it was clearly necessary to acquire more historic objects. However, this demand was not easy to fill and it was met by copies of prints of alchemical laboratories and replicas. Priestley's apparatus, Dalton's atomic diagrams, and De Chancourtois' telluric screw were all reproduced for this new gallery. Models were also popular, including stereochemical models and models of different proposals for the structure of benzene. More modern developments were represented by radioactive minerals and salts, electroanalytical apparatus, and apparatus for the study of explosives. The key objects in the new gallery tended to emphasize chemical achievement and British chemical achievement in particular, with artifacts such as Faraday's benzene, Crookes' thallium samples, and Tilden's synthetic rubber (Barclay 1927, p. 6). Synthetic dyes were also prominent, but curiously there were no artifacts relating to Perkin's synthesis of mauve. Oxygen liquefaction continued to be prominent with Hampson's liquefier joining the earlier Cailletet apparatus. Unusually for the period, there was considerable attention given to biochemistry, and there were exhibits which illustrated the formation of vitamins $\mathrm{A}$ and $\mathrm{B}$ and the preparation of insulin. For many visitors, especially the younger ones, the centerpiece of the 1926 gallery was the periodic table which was used to display the Bonaparte collection. The cases were the same ones that had been used in the Western Galleries and they were still packed close together, but there was perhaps somewhat greater use of graphics, mainly charts, to explain what was on display. The method of writing the captions had been revised, to make them more comprehensible to the general visitor, with a brief non-technical description in bold, followed by a longer technical explanation. By order of the 
director, no caption could now be longer than 400 words (Follett 1978, p. 101).

Chemistry was now displayed as a subject with a long history stretching back to the alchemists and Paracelsus and even as far back as the ancient Egyptians - the Science Museum was fascinated by the ancient Egyptians in this period. Notwithstanding this ancient lineage, it was now developing rapidly and chemists were making major discoveries not least in Britain. The 1926 gallery also emphasized the usefulness of chemistry, not only in making new things and helping medicine but also by giving us a better understanding of a wide range of processes. Again, we cannot be certain of the arrangement of the themes in the gallery in the absence of a floor plan, but the 1927 catalogue began with the "Evolution of Chemistry" up to the time of Thomas Graham, then divided the objects by sub-disciplines ("Theoretical and Physical Chemistry", "Inorganic Chemistry", and "Organic Chemistry") followed by "Laboratory Apparatus", all of which were further subdivided into topics such as "Classification of the Elements", "Natural Dyes", and "Filtration Apparatus" which may correspond to specific cases or sets of cases.

Aimed at the general visitor rather than the chemical educator, the gallery did now promote chemistry in a fairly understated manner. There was thus a shift from making the gallery appealing to the curators' constituency directly towards making it appealing to the general public in a manner that would meet the approval of this constituency. Given that academic and academically trained chemists formed the vast majority of this constituency, the gallery emphasized the intellectual respectability and skillfulness of chemistry. This motif was to be continually repeated in later chemistry galleries at the Science Museum up to the end of the 20th century.

\subsection{The 1977 Redisplay}

Following the post-war reinstatement of chemistry in the 1950s in Gallery 66 on the third floor, chemistry was moved to Galleries $41-43$ on the second floor of the East Block. The space devoted to chemistry increased from 8,300 square feet before 1939 to 11,900 square feet. This new set of galleries was partly funded (£ 30K) by the Association of British Chemical Manufacturers, half the money coming from ICI. Frank Greenaway was the moving force behind this redisplay of chemistry which was opened to the public in 1964 although he did not become Keeper until 1967.

I have chosen here to examine the subsequent redisplay of 1977 rather than the original display of 1964 . This version survived for longer - 22 years against 13 years and I was personally familiar with it, being in charge of it for 8 years. I was also able to discuss this redisplay in detail with Robert Anderson whose personal recollections greatly assisted my analysis. The renovation of the galleries in 1977 was overseen by Frank Greenaway, but the then As- 
sistant Keeper Robert Anderson was effectively in charge. In contrast to the 1964 gallery, there was no industrial funding, but the Royal Institute of Chemistry was celebrating the $100^{\text {th }}$ anniversary of its predecessor, the Institute of Chemistry and it did play a role in the development of the gallery. Nonetheless the government through the Department of Environment's Property Services Agency was still the major sponsor of the gallery in terms of direct input into its construction and indirect financial support. The main constituency remained chemists and chemical educators, but the scientific instrument makers had almost entirely disappeared, a major change even since 1964. On the other hand, historians of chemistry had become an important element of the curators' constituency. It is fair to say that any chemistry gallery from this period onwards had to pass muster with the historians of chemistry as a group. The target audience was "The curious but uninformed 16 year old and above" and independent adults (Anderson 2005).

The goal of the redisplay was to show recent changes in chemistry but portray its history as well, with an emphasis on analysis, structure determination, and archaeological chemistry. The curators strove to "broaden out the chronological and thematic coverage beyond that previously attempted" (Anderson 2006). The development of the new displays was strongly influenced by Anderson's close links with the chemistry department at Oxford and the influence of Professor Edward Hall who had set up an archaeological research laboratory at Oxford. Objects acquired from Oxford included a pioneering infrared spectrometer built by Harold Thompson, Leslie Sutton's electron diffraction apparatus, and the large NMR magnet used by Rex Richards. Objects associated with the early development of gas chromatography including Archer Martin's gas density balance, Tony James's gas chromatograph, and an electron capture detector made by James Lovelock were also obtained. Other important acquisitions were associated with X-ray crystallography: the metal plates used in James Watson and Francis Crick's DNA model, Kendrew and Perutz's model of myoglobin (the so-called 'forest of rods') and Kathleen Lonsdale's apparatus and models. By contrast, the more historical sections of the gallery were shaped by Anderson's work on the Playfair Collection at the Royal Scottish Museum and his interest in alembics, as evidenced by his acquisition of a medieval Islamic alembic at an auction. Some of Joseph Black's glassware was borrowed from the Royal Scottish Museum and there was a panel about Edinburgh's 'Mortar Willie', an $18^{\text {th }}$-century grinder called William Wilson.

The cases were modern aluminum showcases with low-level internal illumination. They were less close-packed than in the 1920s. The displays combined objects with illustrations and original documents and the captions were similar to the two-level captions in the 1926 gallery. The technical part was detailed, and with more historical information than the earlier captions which 
made them sometimes rather long. The three galleries all had a different theme. Gallery 41 which linked the other two galleries was about the "Evolution of Chemistry" to borrow the phrase used in the 1927 catalogue. It began with a small case about alchemy and went via gas chemistry and Thomas Graham to Ramsay on one side, and dealt with great British chemists (Dalton, Davy, Faraday, and Wollaston) on the other side. Gallery 42 was very much about the practical applications of chemistry, with displays of heating apparatus, hydrometers, oil testing apparatus, and, from more recent times, gas chromatography to give some prominent examples. A chronological sequence of chemical balances were displayed - with the scholarly assistance of Peta Buchanan - to illustrate historical continuity. One side of this gallery was dominated by four reproduction laboratories: assaying in the $15^{\text {th }}$ century, the Government Chemist's Laboratory from around 1897, a typical laboratory of the 1960s (the former "Modern Laboratory" of the 1964 gallery), and a modern archaeological research laboratory. By contrast Gallery 43 was rather about academic chemistry, with a prevailing theme of the determination of the composition and structure of molecules by various means; for example, combustion analysis, UV spectroscopy, X-ray crystallography, NMR, and electron diffraction. The latest version of the periodic table - extended to cover all the non-radioactive elements with the assistance of William Griffith of Imperial College - stood at the corner between Gallery 41 and Gallery 43 until it was dismantled in 1986.

The 1977 redisplay presented an image of chemistry which had much in common with its predecessors, obviously there was much overlap with the 1964 gallery as it was only a redisplay of those galleries - a redisplay which was furthermore produced under physical and financial constraints - but also with the 1925 displays in Gallery 66. Chemistry was presented as a science with a long history of practical applications, stemming back to the ancient Egyptians, which had developed rapidly during the 20th century. It showed that British chemists had made a major contribution to its development, especially since the early $18^{\text {th }}$ century. The gallery demonstrated the value of chemistry for our growing understanding of life's mechanisms, especially by the determination of increasingly complex chemical and biochemical structures. It used analytical apparatus and chemical balances to illustrate the importance of precise measurement. The overall impression was that the practice of chemistry required intricate skills from early $19^{\text {th }}$-century blowpipes to the latest electron diffraction. It thus promoted chemistry both as an intellectual challenge and a highly skilled craft rather than concentrating on the benefits of chemistry to the public at large - this task was undertaken, insofar as it was addressed, by the neighboring industrial chemistry gallery. 


\section{4 'Chemistry of Everyday Life', 1999}

In 1999, the three Chemistry Galleries (Galleries 41-43) were cleared and replaced by a new Chemistry Gallery on the eastern side of Gallery 41. This was a much smaller gallery, with only $13 \%$ of the original space. The gallery was developed by Senior Curator Peter Morris. There was no direct sponsorship for this gallery but it was indirectly sponsored by the Analytical Division of the Royal Society of Chemistry (RSC) as it provided a setting for three interactives which had been developed by the RSC in collaboration with the museum. The space was also the home for two large molecular models, including the famous 'forest of rods' model of myoglobin, that had come from the Laboratory of Molecular Biology in Cambridge which was another indirect influence on the gallery. The constituency, as before, was mainly leading chemists and biochemists, and historians of chemistry. Part of the new gallery had been a temporary exhibition ('New for Old') a year earlier based on a close collaboration with scientific instrument suppliers. The collaboration continued while the gallery was under development, so this sector was again part of the constituency. In addition, however, the needs of the gallery's audience were taken into account using the results of visitor surveys carried out by the museum's audience research unit.

The title of the gallery was 'The Chemistry of Everyday Life' and its goal was to show the contribution of chemistry to everyday life, specifically through quality control, and to our understanding the biochemistry of life. It also aimed to illustrate how chemistry, especially analysis and organic chemistry, had developed since 1800 . The display was designed to be a series of contrasts, between pure and applied chemistry, between the chemical apparatus of the late nineteenth century and modern digital chemical equipment, and between the scientific and the personal life of chemists, for instance, Charles Friedel's sword and Marcelin Berthelot's fez. The target audience was family groups with children over 14 , independent adults, university and college students, not very different from the audience for the 1977 redisplay.

The new acquisitions for the gallery were mainly modern examples of chemical equipment, such as a pencil-sized $\mathrm{pH}$ meter, a digital polarimeter, and a FTIR spectrometer. Some artifacts were very similar to Victorian predecessors in their basic operation, but the modern versions looked different, for example, the Tintometer or the Pensky-Marten flashpoint apparatus. Another key acquisition was the donation of an early NMR magnet by Jack Powles which had the virtue of being small enough to go into the display case. The key objects in the gallery were a combination of molecular models ranging from Dalton's wooden atoms and an early glyptic model kit to Hodgkin's model of insulin and the 'forest of rods' - and classic scientific instruments including the Beckman Model G pH meter, the Beckman DU ultraviolet spectrometer, and the Perkin-Elmer Model 21 infrared spectro- 
photometer. I also made a point of displaying a number of historic chemicals including alkaloids isolated by Pelletier and Caventou, fatty acids prepared by Chevreul, and chemicals synthesized by Wurtz, Friedel, and Grignard. The gallery had one long wall case and for a while it had a large freestanding case which housed the large molecular models. Originally it also had three freestanding interactives, which were the first interactives in a pure chemistry gallery at the Science Museum, although there had been interactives in the earlier Industrial Chemistry Galleries. Subsequently, they were moved to make way for a temporary exhibition and were not replaced, partly because they had started to become faulty even after only a year. Information panels replaced the traditional captions and the objects had only very brief identifying labels. It was originally intended to supply additional information about the artifacts and the displayed chemists on computer screens outside the cases, but in the end the necessary funds were not available.

The image of chemistry presented in this gallery is a science which contributes to everyday life in unexpected ways, through quality control and analysis rather than wonderful new products. It also shows the ability of chemists to decode the structure of huge molecules such as myoglobin and the enduring significance and usefulness of molecular models. The gallery illustrates the enormous changes in chemistry over the last two centuries but also reveals that many techniques have remained the same, but in a new casing and with the addition of electronics and then computers, either alongside the instrument or within it as a microchip. This gallery, probably the last of its kind at the Science Museum, thus stands in a long tradition of showing the importance of chemistry in understated terms of its basic utility rather than through spectacular achievements or amazing products. In historical terms, the 1999 gallery reverts to the late Victorian presentation of chemistry as a comparatively recent science rather than one with an ancient lineage. This was partly a result of a severe lack of space but also stems from recent historiography which portrays chemistry as a largely $19^{\text {th }}$-century creation which sought legitimacy by claiming an ancestry from alchemy, metallurgy, and natural philosophy.

\section{Chemistry in the Deutsches Museum}

It would be desirable, and indeed logical, to compare the image of chemistry presented by the Science Museum with leading science and technology museums in other countries. In practice, however, it is only possible to make a proper comparison with the Deutsches Museum in Munich. This is partly a matter of available sources, I only have access to an adequate number of 
guides for the period from 1930 to the present in the case of the Deutsches Museum, but also a reflection of the amount of space devoted to chemistry in other major museums. The Smithsonian only gave over a small amount of its exhibition space to chemistry, as opposed to materials, until the opening of 'Science in American Life' in April 1994. The Conservatoire national des arts et métiers in Paris has the famous reconstruction of Lavoisier's laboratory and its associated artifacts, but little else connected with chemistry.

According to Elisabeth Vaupel, the format of the pure chemistry galleries on the first floor of the Deutsches Museum was developed for the opening of the museum in 1906 by three leading chemists, Hans Bunte, Walther Nernst, and, above all, Wilhelm Ostwald, who had a strong interest in the history (and philosophy) of chemistry (Vaupel 2003). As well as drawing on their own experience as teachers of chemistry, the three professors drew on the World Fairs for inspiration. Certainly their schema was very different from the Science Museum's Western Galleries. The chemistry galleries were divided into three roughly equal parts: the history and development of chemistry, the contemporary science, and finally what we would now call an interactive section where visitors could carry out their own experiments. While the Science Museum did adopt a mixture of history and contemporary chemistry in the 1920s, there was certainly no interactive elements at all until 1999, and even then only briefly. Underpinning this approach, with its expensive use of chemicals and other materials in the interactives, was massive financial support from the German chemical industry, which was at its peak in the early years of the $20^{\text {th }}$ century. The scale and the continuity of this support are in stark contrast to the Science Museum where only one set of pure chemistry galleries (1964) has received any significant financial support from industry. With the obvious exception of the content of the contemporary chemistry section, the basic plan drawn up by Bunte, Nernst, and Ostwald has remained largely unchanged up to the present day (Deutsches Museum Guides 1930, $1957,1968,1988$, and 2000). Industrial chemistry was originally an integral part of the chemistry gallery, as it was at the Science Museum between 1912 and 1939, but a chemical technology gallery was opened on the second floor in 1965, which displayed the chemistry of everyday life as well as process engineering and industrial processes (Rehn 2006). This gallery was replaced in 1979 by a gallery on the first floor which dealt with industrial chemistry with an emphasis on chemical products, rather than processes, and the use of chemistry in medicine (Deutsches Museum Guide 1988, pp. 173-179). This in turn was closed in 1998 and replaced by a gallery on pharmacy in 2000.

Three reconstructed laboratories have always been the mainstay of the historical section of the chemistry gallery at the Deutsches Museum. The alchemical laboratory (based largely on Agricola) is linked to the development of distillation, herbs, and iatrochemistry. The Science Museum intro- 
duced a similar laboratory based on Agricola in 1964, but was careful to describe it as an assaying laboratory (not alchemical, a distinction lost on nearly all the visitors) and placed it within the context of metallurgical analysis by blowpipes and balances. This is followed by a "laboratory of the $18^{\text {th }}$ century" which according to the 1930 guide contained a range of apparatus from Boyle's period through Priestley and Cavendish to Lavoisier. It is interesting that no attempt was made to place this laboratory within the context of German chemistry in this period, for instance, by Stahl, Wiegleb, and Gren. All of this leads up to the central exhibit, Liebig's laboratory. But this is the Liebig of the Munich period rather than Giessen, which is not surprising given the museum's location. There never has been a parallel at the Science Museum to Liebig's laboratory or to Lavoisier's laboratory in the Conservatoire. The equivalent period in the 1964 gallery, the first gallery to have reconstructed laboratories (previously the museum had used small dioramas to show laboratories), was the Government's Chemist's laboratory which puts the emphasis on public service and utility rather than greatness. The space devoted to contemporary chemistry is simply a series of exhibits relating to the structure of matter, including the periodic table, and modern chemical apparatus for analysis and synthesis as there were "so many subsections in modern chemistry, it was impossible to show a typical modern laboratory in one room" (Deutsches Museum Guidebook 1930, p. 48). After World War II, this section was described in the guidebook as a "modern laboratory", but I suspect this was more a shift of presentation in the guidebook than any change on the museum floor (Deutsches Museum Guide, 1957, p. 32). The numerous interactives are embedded within the display of modern chemistry. They are a striking feature of the Deutsches Museum's presentation of chemistry and are only possible because of the chemical industry's financial support. It is difficult to assess how they affect the visitors' image of chemistry. From personal observation, some visitors find them interesting but others are alienated by the technical complexities. My own view is that in trying to make chemistry more accessible many of the interactives actually make chemistry appear incomprehensible 'magic in a box'.

What is the image of chemistry portrayed by the Deutsches Museum's galleries? It has always emphasized the long history of chemistry, although not as far back as the Science Museum's ancient Egyptians. The development of chemistry is largely seen through its intellectual development and fundamental principles. In contrast to the Science Museum, there appears to be less emphasis on specific discoveries, but this is perhaps a matter of emphasis rather than a significant difference. In the Deutsches Museum's presentation, chemistry has developed rapidly but mainly in the $20^{\text {th }}$ century. There is a curious gap in the late $19^{\text {th }}$ century, which is very evident in the 1930 guide. The Deutsches Museum emphasizes the numerous sub-divisions of modern 
chemistry instead of its many ways of doing things, perhaps a Germanic concern with structure rather than action. While the Science Museum, at least in the pure chemistry galleries, has presented chemistry as the useful science across a broad front, the Deutsches Museum has focused on its role within the chemical industry, perhaps inevitably so given its main source of funding. The 1930 gallery had a 'hall of honor', a parallel to the museum's main Ehrensaal (now translated as the 'Hall of Fame'), but this was dedicated to "famous founders of the German chemical industry" not famous academic chemists. Both the Science Museum and the Deutsches Museum have consistently highlighted the contribution of chemistry to medicine and physiology, although the Germans in the 1930s seemed curiously interested in the relationship between the energy content and the cost of food, perhaps a reflection of the cost of food in Germany at the time.

Given the strength of German chemistry in 1906, and for some time afterwards, the chemistry galleries at the Deutsches Museum were surprisingly international even in the (early) 1930s. The detailed description of the chemistry galleries in the 1930 guidebook mentions six German chemists and alchemists (Agricola, Ercker, Liebig, Mitscherlich, Bunsen, Wöhler), three British chemists (Boyle, Priestley, Cavendish), two Swedish chemists (Scheele, Berzelius) and a French chemist (Lavoisier). It is difficult to make a direct comparison with the Science Museum, but there was definitely a strong bias towards British chemists until the 1999 gallery gave over some of its limited space to French chemists. In the 1977 redisplay, there were 19 cases in the historical display in Gallery 41 devoted to British chemists and only the equivalent of 2 cases to foreign chemists (Lavoisier, van Helmont, Kipp, and Döbereiner).

\section{Conclusions}

The most striking feature of this study of chemistry in museums has been the persistence of a particular style of presenting chemistry in a given museum during the $20^{\text {th }}$ century. The Science Museum did shift ground, especially in its presentation of historical chemistry, in the 1920s but has remained faithful to the model adopted in 1923 for the last eighty years. The basic format of the chemistry displays at the Deutsches Museum has been unchanged since it opened in 1906. The Conservatoire has always concentrated on Lavoisier. The Smithsonian (in its current guise as the National Museum of American History) is the exception. Its 'Science in American Life' gallery is very different from earlier presentation of chemistry - even the focus of the reconstructed laboratory switched from Priestley to Remsen - and this is currently 
the only chemistry gallery which draws extensively on the modern historiography of science and technology. It has been criticized for presenting too negative a view of science but it also stands in a broad tradition of being fairly neutral in its support of chemistry and science. It may be more quizzical about the benefits of science than its counterparts elsewhere, but none of the leading chemistry galleries have promoted chemistry in the extravagant manner of many popular books on chemistry, the archetype of the latter of course being A. Cressy Morrison's Man in a Chemical World (1937). But if all the chemistry galleries have been quietly understated in their support of chemistry, there are differences between them. The Science Museum (along with the Conservatoire and the Smithsonian) has always been immensely dependent on state funding and thus it has always highlighted on the public value of chemistry (medicine and quality control) and the use of chemistry by the state (notably the Laboratory of the Government Chemist). The Deutsches Museum on the other hand, although formally administered by the State of Bavaria, has always been associated, as far as chemistry is concerned, with the German chemical industry. Its galleries have thus concentrated on the products of the industry, including scents in the pre-World War II period, rather than the use of chemistry as a service science.

While these institutional contexts are important, I would argue that the chemistry galleries at the Science Museum, and probably elsewhere, have hitherto been shaped not so much by curators (although they decide the exact form of the displays), the overseers of the museum (the Director, Advisory Council, Board of Trustees) or less still, by visitors, but by an external constituency that curators have sought to please. The composition of this group remained fairly constant during the $20^{\text {th }}$ century. They comprised leading academic chemists, if not usually Nobel Laureates like Nernst and Ostwald, chemical educationalists, and state-employed chemists. Chemical industrialists have generally not had much influence on the pure chemistry galleries and popularizers of science have had even less impact. As they have grown in number and professional status, historians of chemistry have become members of constituency but generally have had less influence than chemists. This is partly because the curators have become historians of chemistry themselves and partly because the history of instruments has been very much a minority interest in the history of chemistry. To some extent the historians have hitherto had a veto rather than a direct influence. Up to now a new gallery had to be acceptable to them, i.e. avoid any major errors or excessive Whiggism, rather than positively appeal to them or incorporate the latest historiography.

The galleries at the Science Museum, and as far as I can tell at the Deutsches Museum, have portrayed chemistry as a science which has a long history, with particular reference to the breadth and variety of chemistry. This image has been presented in a carefully crafted and exquisitely balanced 
- almost low-key - manner emphasizing skilful practice rather than controversy. The image of chemistry presented in this way has been positive - largely chemistry as useful - without making any extravagant claims for chemistry or chemists. On the other hand, criticism has also been muted, indeed almost invisible. In keeping with the neutral stance of the civil service, emotion and all matters touching on politics or religion have hitherto been strenuously avoided.

Has the Science Museum changed or at least influenced people's perception of chemistry? Has the low-key approach been successful where boosterism has failed? The focus of this paper has been on the image of chemistry presented by museums from within. A paper on the impact of museum galleries on the public perception of chemistry would require a completely different methodology and additional sources of information, such as visitor surveys, public opinion polls, and the like. Furthermore this information would be mostly lacking for the interwar period when museums may have had their greatest impact. Nonetheless it is possible to make a few generalizations. Although millions of people visit science museums, this activity is still a minority activity. According to a Eurobarometer survey in $2002-3$, only $11 \%$ of respondents in the old EU of 15 countries had visited science and technology museums in the previous year and the figure for the new members of the EU was even lower (Gallup 2003). Furthermore, the media is in a far stronger position to shape people's perception of chemistry than museums. People are constantly bombarded by the media through newspapers, radio, television, and increasingly via the Internet, whereas a museum visit will last only a few hours at most. On the basis of the experience of Oliver Sacks and the late John Stock, I infer - and in the absence of hard evidence, it can only be a surmise - that traditional chemistry galleries were inspirational in the "chemistry-set era' from 1920s to early 1960s when suitably enthused visitors could go home and develop their new-found interest by producing exciting bangs and smells in the garden shed (Sacks 2001, Stock 2004). I also strongly suspect that the galleries appealed mainly to boys rather than girls, and to children aged 10-14 rather than older teenagers. It is impossible to even guess how many young visitors were stimulated to take an interest in chemistry in this way and how long their enthusiasm survived on average. Given that we know the profound effect it had on some visitors, the results for chemistry in terms of an improved image and recruitment to the profession - must have been generally positive if inevitably limited in terms of the number of people thus influenced.

Science and technology museums are going through a period of great change. Interactivity is now central to the museum visit and this works against chemistry which is not easy to turn into attractive interactives despite the Deutsches Museum's best efforts. As the practice of science becomes 
increasingly interdisciplinary and the teaching of science becomes largely the teaching of general science at least in Britain, the single-discipline gallery has become outmoded. The first gallery in a major science museum to completely integrate different scientific disciplines was the 'Science in American Life' gallery at the National Museum of American History which opened in 1994. This is not wholly surprisingly as the galleries at the Washington museum were always multi-disciplinary if not interdisciplinary (Smithsonian Guide 1976). The Science Museum's multidisciplinary science gallery is projected to open in 2009, the museum's centenary year. This gallery will be built around the themes of belief, power, and trust, and will cover astronomy, mathematics, physics, geophysics, and biomedicine as well as chemistry. A particular feature of this gallery will be its coverage of non-western science. The goal of this gallery is to promote scientific citizenship by illustrating the relationships which have existed and currently exist between science and its publics and within science. The target audience will have a significantly lower age limit than the chemistry galleries considered here, as the new gallery is aimed at school groups aged 10 and above, parents with children aged 10 and above, and independent adults. Chemistry will be well represented in the science gallery but inevitably its footprint in the Science Museum will be much smaller than in the period when there were three chemistry galleries (1964-1999). The Deutsches Museum is also transforming the way it presents chemistry with the aim of opening a new chemistry gallery in 2008. One way or another, museum curators will continue to present chemistry in new multidisciplinary and historiographically sophisticated contexts which will draw on the best museological traditions while also developing new ways of encouraging visitors to take science seriously.

\section{Acknowledgements}

I wish to acknowledge the enormous debt I owe to John Liffen, the curator of telecommunications at the Science Museum, who is a fount of knowledge about all aspects of the museum's history. I am also very grateful to my predecessors at the Science Museum, Dr. Robert Anderson and Dr. Derek Robinson for their recollections and comments, and to my colleagues Dr. Robert Bud and Dr. Tim Boon for their feedback. I would also like to thank Dr. Susanne Rehn for her remarks on the section about the Deutsches Museum. Of course, all mistakes that remain are wholly my own. 


\section{References}

All the non-archival sources cited here, except the private communications and the online document, are available at the Science Museum Library. The unpublished Annual Reports of the Science Museum and much of the published Science Museum material are kept in the semi-rare book room. In addition to these sources, I also had access to the chemistry curator's collection of gallery photographs and a set of labels with floor plans for the 1977 Gallery.

Anderson, R.G.W.: 2005, private communication, 11 August.

Anderson, R.G.W.: 2006, private communication, 2 February.

Barclay, A.: 1927, Catalogue of the Collections in The Science Museum, South Kensington, with Descriptive Notes and Illustrations. Chemistry, His Majesty's Stationery Office, London.

Board of Education: 1909, Reports for the Year 1908 on The Geological Survey, The Geological Museum in Jermyn Street, The Science Museum at South Kensington and the Work of The Solar Physics Committee, His Majesty's Stationery Office, London, pp. 26 and 29.

Board of Education: 1924a, Report for the Years 1921 and 1922 on The Science Museum, His Majesty's Stationery Office, London, p. 15.

Board of Education: 1924b, Report for the Year 1923 on The Science Museum, His Majesty's Stationery Office, London, pp. 6, 15.

Board of Education: 1926, Report for the Year 1925 on The Science Museum, His Majesty's Stationery Office, London, p. 21.

Board of Education: 1931, Report of the Advisory Council of The Science Museum for the Year 1930, His Majesty's Stationery Office, London, p. 31.

Catalogue: 1906: Catalogue of the Science Collections for Teaching and Research in the Victoria and Albert Museum. Part III. Chemistry, His Majesty's Stationery Office, London.

Deutsches Museum Guide: 1930, Deutsches Museum von Meisterwerken der Naturwissenschaft und Technik, Munich, Brief Guide Official Edition, Deutsches Museum, Munich, pp. 47-50.

Deutsches Museum Guide: 1957, Deutsches Musenm of Masterpieces of Natural Science and Technology, Munich, Short Guide Through the Collections, $1^{\text {st }}$ edn., Deutsches Museum, Munich, pp. 31-33.

Deutsches Museum Guide: 1968, Deutsches Museum of Masterpieces of Natural Science and Technology, Munich, Illustrated Guide Through the Collections, $5^{\text {th }}$ edn., Deutsches Museum, Munich, pp. 59-61.

Deutsches Museum Guide: 1988, Deutsches Museum Guide throngh the Collections, Deutsches Museum, Munich, pp. 164-172.

Deutsches Museum Guide: 2000, Guide to the Museum, $2^{\text {nd }}$ rev. edn., Deutsches $\mathrm{Mu}-$ seum, Munich, pp. 72-75.

Follett, D.: 1978, The Rise of the Science Museum under Henry Lyons, Science Museum, London.

Gallup: 2003: Candidate Countries: Eurobarometer: Public Opinion in the Countries Applying for European Union Membership. CC-EB 2002.3 on Science E Technology. The Gallup Organisation, Hungary. [http://europa.eu.int/comm/ public_opinion/archives/cceb/2002/2002.3_science_technology.pdf, accessed on 24 January 2005]. 
Hobhouse, H.: 2002, The Crystal Palace and the Great Exhibition: Science, Art and Productive Industry: a History of the Royal Commission for the Exhibition of 1851, Athlone, London.

Macdonald, S.: 2002, Behind the Scenes at the Science Museum, Berg, Oxford.

Morrison, A.C.: 1937, Man in a Chemical World: The Service of Chemical Industry, Scribner's Sons, New York.

Rehn, S.: 2006, private communication, 25 January (citing the Deutsches Museum's Jabresberichte).

Sacks, O.: 2001, Uncle Tungsten: Memories of a Chemical Childhood, Picador, London.

Science Museum: 1968, "Report of the Science Museum for the Year 1967” (mimeographed).

Science Museum: 1970, "Report of the Science Museum for the Year 1969" (mimeographed).

Science Museum Guide: 1937, Science Museum. Outline Guide to the Exhibits, His Majesty's Stationery Office, London, p. 30.

Science Museum Guide: 1952, Science Museum. Outline Guide to the Exbibits, His Majesty's Stationery Office, London.

Science Museum Guide: 1953, Science Museum. Outline Guide to the Exhibits, His Majesty's Stationery Office, London.

Science Museum Guide: 1957, Science Museum. Outline Guide to the Exhibits, His Majesty's Stationery Office, London.

Smithsonian Guide: 1976, Official Guide to the Smithsonian, CBS Publications, pp. 29-31.

Special Loan Catalogue: 1876, Catalogue of the Special Loan Collection of Scientific Apparatus at the South Kensington Museum, MDCCCLXXVI, $3^{\text {rd }}$ edn., Her Majesty's Stationery Office, London.

Stock, J.: 2004, ‘Pilgrim’s Progress: The London Science Museum: A Chemical Reminiscence', Chemical Heritage, 22 (3), 10-11, 38-9.

Vaupel, E.: 2003, 'Scientific chemistry', in: W.P. Fehlhammer (ed.) Deutsches Museum: Ingenious Inventions and Masterpieces of Science and Technology, Prestel, Munich, p. 132.

Who Was Who: 1991, Who Was Who, vol. VIII, Black, London, p. 39.

Z Archive: 1924, Notes by the Director [H. J. Lyons] and by Alexander Barclay, both dated 11 March in Scheme for development file ED 79/141 "Pure chemistry, 1923-1955”.

Peter Morris:

The Science Museum, Exhibition Road, London SW7 2DD, U.K.;

peter.morris@nmsi.ac.uk 